\title{
Uromucoid (Tamm-Horsfall glycoprotein) forms different polymeric arrangements on a filter surface under different physicochemical conditions
}

\author{
Roger C. Wiggins \\ Department of Internal Medicine The University of Michigan Ann Arbor, MI (USA)
}

(Received 14 December 1985; revision received 25 September 1986; accepted after revision 8 October 1986)

Key words; Uromucoid glycoprotein; Tamm-Horsfall protein

\section{Summary}

Normal human urine cannot be forced through a $0.2 \mu \mathrm{m}$ filter. To investigate the reason for this phenomenon, uromucoid (Tamm-Horsfall protein) was purified from human urine and its capacity to block a $0.2 \mu \mathrm{m}$ Millipore filter was measured under different conditions. In the presence of cations $\left(\mathrm{H}^{+}, \mathrm{Na}^{+}, \mathrm{Ca}^{2+}\right)$ uromucoid blocked the filter. The blocking varied with cation concentration. Scanning electron microscopy of the filter surface revealed different arrangements of polymerized uromucoid coating the filter surface depending on ionic conditions. In the presence of $100 \mathrm{mmol} / 1 \mathrm{NaCl}$ or $1 \mathrm{mmol} / 1 \mathrm{CaCl}_{2}$ uromucoid polymers were present in a fibrous arrangement. In the presence of both $\mathrm{NaCl}$ and $\mathrm{CaCl}_{2}$ a dence mat of uromucoid polymers was present together with clumps of aggregated polymer. In the absence of ions uromucoid formed a homogeneous coat on the filter surface (as demonstrated by scanning electron microscopy, Western blotting and ${ }^{125} \mathrm{I}$-uromucoid binding studies) but did not block the filter. Similar fibrous and highly aggregated arrangements of uromucoid polymer were seen in hyaline casts from urine. These data are consistent with the concept that the uromucoid glycoprotein can exist in several different polymeric forms under different ionic conditions.

\section{Introduction}

Small amounts of urine block a $0.2 \mu \mathrm{m}$ Millipore filter. In a previous study, the surfaces of filters through which urine had been forced were examined by scanning

Correspondence to: Roger C. Wiggins, M.D., Internal Medicine (Nephrology), 3914 Taubman Health Care Center, University of Michigan, Ann Arbor, MI 48109-0364, USA. 
electron microscopy [14], and found to be coated with fibers. This material could be solubilized with sodium dodecyl sulfate (SDS) and was shown by SDS-PAGE and Western blotting to be uromucoid. In this study, purified uromucoid was used to determine whether it could indeed block filters and to examine the different polymeric arrangements of uromucoid on the filter surface in relation to blocking.

\section{Materials and methods}

\section{Purification of uromucoid protein}

Uromucoid protein was purified from normal human urine by a modification of the method of Tamm and Horsfall [12]. Urine (2-10 1) was collected from normal individuals and $\mathrm{NaCl}$ added to increase the $\mathrm{NaCl}$ concentration by $0.58 \mathrm{~mol} / \mathrm{l}$. Sodium azide was added to a final concentration of $0.02 \%$. The urine was left overnight at $4^{\circ} \mathrm{C}$, and then centrifuged at $3000 \times g$ for $20 \mathrm{~min}$. The pellet was dissolved in water (1/10th original volume) and dialyzed against water for $24 \mathrm{~h}$ with three changes of dialysis. This solution was centrifuged at $1000 \times \mathrm{g}$ for $10 \mathrm{~min}$ to pellet cells. The supernatant was made $1 \%$ with Triton $\mathrm{X}-100$ for $30 \mathrm{~min}$ at $37^{\circ} \mathrm{C}$ to dissolve membrane fragments. $\mathrm{NaCl}$ was then added to $0.58 \mathrm{~mol} / 1$ and left overnight at $+4^{\circ} \mathrm{C}$. The mixture was centrifuged at $50000 \times \mathrm{g}$ for $1 \mathrm{~h}$. The pellet was washed three times in $0.58 \mathrm{~mol} / 1 \mathrm{NaCl}$ prior to being redissolved in water. Following a further $0.58 \mathrm{~mol} / \mathrm{l} \mathrm{NaCl}$ precipitation step as described above the material was extensively dialyzed against water, aliquoted and stored at $-30^{\circ} \mathrm{C}$. The protein concentration was measured by the Lowry method [5] using bovine serum albumin as a standard.

\section{The filter assay}

Filters made of mixed esters of cellulose acetate and nitrate (Millipore Corp, Redford, MA, USA) $0.22 \mu \mathrm{m}$ cut-off $13 \mathrm{~mm}$ in diameter were placed in plastic filter holders (Millipore). Uromucoid protein (from a stock of $4 \mathrm{mg}$ protein $/ \mathrm{ml}$ ) was thoroughly mixed with the buffer system to be tested. The upper chamber of the filter holder was then filled with the test mixture. Mixture was also drawn up into a 3-ml (or 5-ml) plastic disposable syringe (Beckman-Dickinson Division, Rutherford, NJ, USA). Air bubbles were removed. The syringe was fixed to the filter holder, and the plunger depressed with maximum effort until no further fluid could be pushed through the filter. The volume filtered was read directly off the markings on the syringe barrel. Three to ten replicates of each solution were tested.

\section{Scanning electron microscopy (SEM)}

Mixtures containing purified uromucoid protein in various buffers were pushed through a $13-\mathrm{mm}$ diamter $0.2 \mu \mathrm{m}$ filter (Millipore, Bedford, MA) as outlined above. The filters were prepared for scanning electron microscopy as previously described [14].

\section{SDS-polyacrylamide gel electrophoresis and Western blotting}

Following filtration of a solution containing uromucoid protein the filter holder was disassembled. The Millipore filter was removed with fine forceps and rinsed by 
dipping the filter in the buffer used to dilute the uromucoid. The surface of the filter was then washed repeatedly with $100 \mu 1$ of $10 \%$ SDS containing $8 \mathrm{~mol} / 1$ urea, into a $1.5 \mathrm{ml}$ plastic tube to elute any protein non covalently bound to the filter surface.

Samples were analyzed by the SDS-PAGE. They were loaded using the agarose drop technique [13], run with a (Laemmli buffer system [4]) and stained with silver [8]. Western blotting was performed using a goat antiuromucoid serum as previously described [14].

\section{Studies with $\left[{ }^{125}\right.$ IJuromucoid}

Purified uromucoid protein was radiolabelled with ${ }^{125}$ Iodide (New England Nuclear) by the chloramine-T method [15] to a specific activity of $2.2 \mu \mathrm{Ci} / \mu \mathrm{g}$ in the presence of $0.5 \%$ SDS. Following dialysis against $0.1 \%$ SDS in water to remove free ${ }^{125} \mathrm{I} 96.9 \%$ of the ${ }^{125} \mathrm{I}$ was precipitated by $15 \%$ trichloracetic acid. For the experiments described [ ${ }^{125}$ I] uromucoid protein $(0.4 \mu \mathrm{Ci}, 0.2 \mu \mathrm{g})$ was added to unlabelled

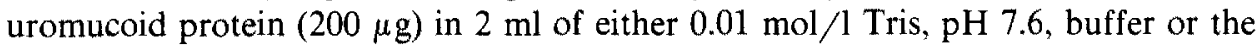
same buffer containing $1 \mathrm{mmol} / \mathrm{I} \mathrm{CaCl}_{2}$. In one part of the experiment, $1 \mathrm{ml}$ of the $0.01 \mathrm{~mol} / \mathrm{l}$ Tris buffer containing $100 \mu \mathrm{g}$ of uromucoid protein spiked with $\left[{ }^{125} \mathrm{I}\right]$ uromucoid protein was easily pushed through a $0.22 \mu \mathrm{m}$ Millipore filter. In the second part of the experiment only $0.6 \mathrm{ml}$ of the [ ${ }^{125}$ I] uromucoid protein mixture containing $1 \mathrm{mmol} / \mathrm{I} \mathrm{CaCl}_{2}$ could be pushed through a similar filter. At the end of the experiment the filter holders were disassembled and the amounts of $\left[{ }^{125}\right.$ I] uromucoid protein in the starting material, the filtrate, and on the filter were measured in a gamma counter. The proportion of ${ }^{125} I$ on the filter was calculated as the percentage of the uromucoid protein which had been pushed through the filter

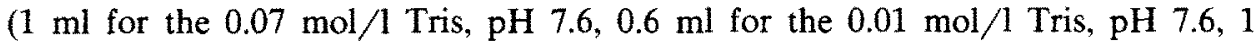
$\mathrm{mmol} / 1 \mathrm{CaCl}_{2}$ ). Experiments were performed in triplicate and expressed as the mean of the three results.

\section{Results}

Uromucoid was purified from normal human urine gave a single protein band of about $80000 \mathrm{~mol}$ wt when analyzed by SDS-PAGE under both reducing and non-reducing conditions (Fig. 1).

The filter blocking assay (see 'Materials and Methods') was used to measure the effect of the uromucoid concentration, $\mathrm{pH}, \mathrm{CaCl}_{2}$, and $\mathrm{NaCl}$ concentrations on the filter blocking capacity of uromucoid. The results are shown in Figs. 2-5.

The relationship between the concentration of uromucoid protein and the filter blocking effect was linear when plotted on a $\log -\log$ plot as shown in Fig. 2. This result is compatible with the conclusion that uromucoid protein accumulates on the filter surface and hlocks movement of water across the filter. Complete filter blocking occurs when fluid containing about $30-50 \mu \mathrm{g}$ of uromucoid had been forced through the filter.

In the absence of $\mathrm{Na}^{+}$or $\mathrm{Ca}^{2+}$ the $\mathrm{pH}$ had a marked effect on the filter blocking capacity of uromucoid protein (Fig. 3), with almost no filter blocking effect at $\mathrm{pH} 8$ or above. In contrast when $\mathrm{Na}^{+}$and $\mathrm{Ca}^{2+}$ were present at concentrations similar to 


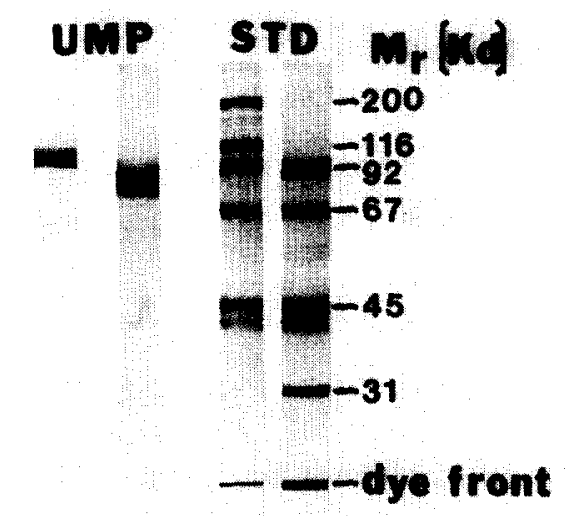

\section{NR R H L}

Fig. 1. SDS-PAGE (10\%) stained with Coomassie Blue for protein. Purified uromucoid (UMP) was run under reducing (R) and non-reducing (NR) conditions. Molecular weight standards (STD) run under reducing conditions are shown in the right two lanes. They include myosin (200000), $\beta$-galactosidase (116000), phosphorylase B (92500), bovine serum albumin (67000), ovalbumin (45000), and carbonic anhydrase $(31000)$. Twenty micrograms of uromucoid was loaded onto each lane. The apparent molecular weight of purified uromucoid glycoprotein under reducing conditions was about 80000 .

those present in the diluting segment of the nephron $\left(\mathrm{Na}^{+} 60\right.$ and $\mathrm{Ca}^{2+} 0.3$ mmol/l, respectively) there was no change in the filter blocking capacity with change of $\mathrm{pH}$ between 5.4 and 8.0 .

Figure 4 shows the effect of changing the $\mathrm{Ca}^{2+}$ concentration while maintaining different ambient $\mathrm{pH}$. The major effect was seen between 0.04 and $0.4 \mathrm{mmol} / 1$

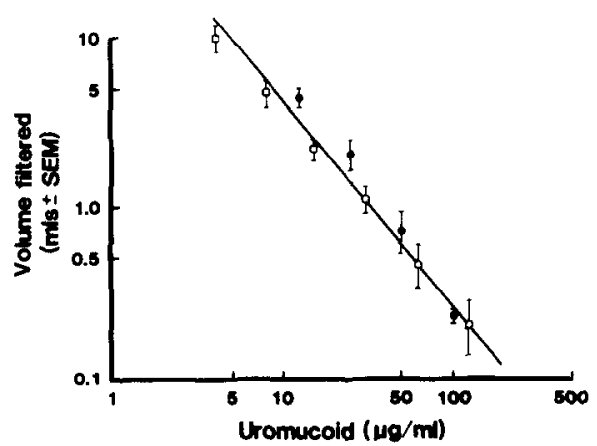

Fig. 2. Relationship between the concentration of uromucoid glycoprotein and the volume of fluid containing the uromucoid which could be forced through the filter. The symbols show data for two different experiments using differing ionic conditions and uromucoid purified in different batches. Note that the filter becomes blocked when fluid containing approximately $30-50 \mu \mathrm{g}$ of uromucoid have been forced through the filter. $\square, 0.15 \mathrm{~mol} / 1 \mathrm{NaCl} ; 0,0.01 \mathrm{~mol} / 1$ Tris, $\mathrm{pH} 7.1+60 \mathrm{mmol} / 1 \mathrm{NaCl}+0.3$ $\mathrm{mmol} / 1 \mathrm{CaCl}_{2}$. 


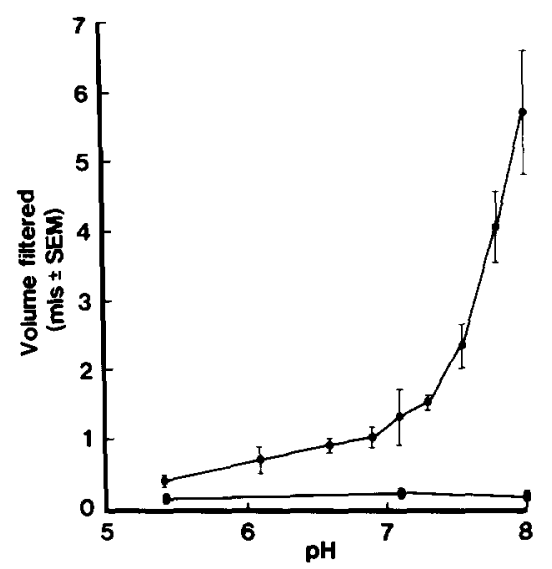

Fig. 3. Relationship between $\mathrm{pH}$ and filterability of a $100 \mu \mathrm{g} / \mathrm{ml}$ solution of uromucoid glycoprotein. Note that in the absence of added ions the filterability of the uromucoid solution is markedly affected by $\mathrm{pH}$. In contrast, addition of ions at concentrations found in the ascending loop of Henle results in uniform blocking of the filter over the whole $\mathrm{pH}$ range tested. $\bullet, 0.01 \mathrm{~mol} / 1$ Tris; $\mathbf{\square}, 0.01 \mathrm{~mol} / 1$ Tris +60 $\mathrm{mmol} / 1 \mathrm{NaCl}+0.3 \mathrm{mmol} / 1 \mathrm{CaCl}_{2}$.

$\mathrm{Ca}^{2+}$. Increasing the $\mathrm{pH}$ to 7.6 decreased the water barrier effect of any given $\mathrm{Ca}^{2+}$ concentration. However, at pH 5.4 the filter was blocked even in the absence of $\mathrm{Ca}^{2+}$.

The effect of $\mathrm{Na}^{+}$is shown in Fig. 5 where increasing $\mathrm{Na}^{+}$from $10-250 \mathrm{mmol} / 1$ was accompanied by an increasing filter blocking effect. At very high concentrations uromucoid tended to aggregate (see below) and lose its filter blocking effect.

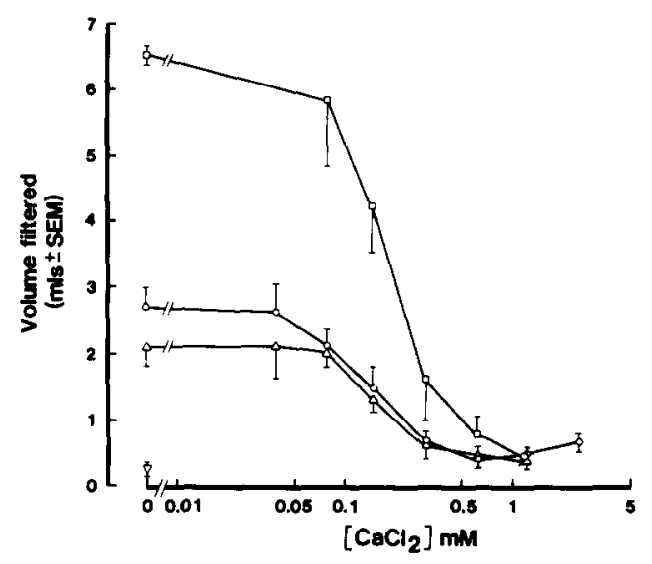

Fig. 4. Relationship between filterability of a solution of uromucoid $(100 \mu \mathrm{g} / \mathrm{ml})$ and the ambient $\mathrm{Ca}^{2+}$ concentration at different $\mathrm{pH}$ ranges. Note that the effect of $\mathrm{Ca}^{2+}$ is seen hetween 0.04 and $04 \mathrm{mmol} / 1$ and that at $\mathrm{pH} 5.4$ the filter is maximally blocked in the absence of added $\mathrm{Ca}^{2+} . \square, \mathrm{pH} 7.6 ; \mathrm{O} \mathrm{pH} 7.1 ; \Delta$, $\mathrm{pH} 6.6 ; \nabla, \mathrm{pH} 5.4$. 


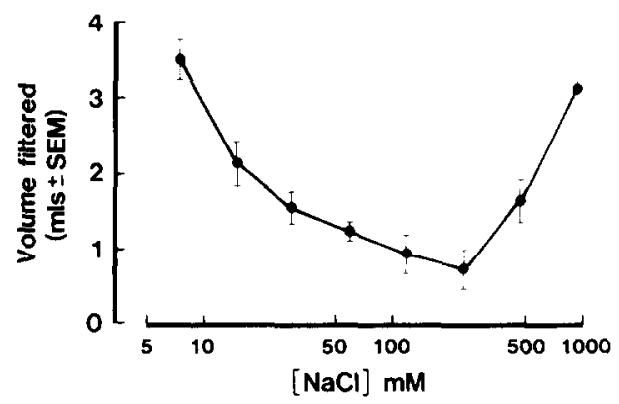

Fig. 5. Relationship between filterability of a solution of uromucoid $(50 \mu \mathrm{g} / \mathrm{ml})$ and the ambient sodium concentration at $\mathrm{pH}$ 7.1. An effect of $\mathrm{Na}^{+}$is seen over the range 10-250 mmol/1. At higher concentrations more fluid passes across the filter probably due to aggregation of uromucoid.

Taken together these data indicate that when $\mathrm{Na}^{+}, \mathrm{Ca}^{2+}$ and $\mathrm{pH}$ vary over the ranges expected to be present in the nephron, these changes have little effect on the filter blocking effect of uromucoid.

To study the anatomical arrangement of uromucoid on the filter surface uromucoid was pushed through filters under various conditions. The filters were then fixed with glutaraldehyde and examined by scanning electron microscopy. Figure 6 panel $\mathrm{A}$ shows the structure of the filter surface itself in the absence of uromucoid. Panel B shows the effect of uromucoid in $0.01 \mathrm{~mol} / 1$ Tris, $\mathrm{pH} 7.6$ (conditions where the filter was not blocked), where the filter surface appeared to be smoothly coated with uromucoid (the presence of the uromucoid on the filter is confirmed by other experiments described below). In the presence of $\mathrm{Ca}^{2+}(1$ $\mathrm{mmol} / 1)$ or $\mathrm{Na}^{+}(100 \mathrm{mmol} / 1)$ (blocked filter) the uromucoid formed fiber-like arrays on the filter surface (Panels $C$ and $D$, respectively). The fibers appear to be about $20 \mathrm{~nm}$ thick and up to $1000 \mathrm{~nm}$ long and to be decorated with blobs about 30 $\mathrm{nm}$ in diameter. These values for thickness do not take into account approximately $10 \mathrm{~nm}$ of gold/palladium coating (see 'Materials and Methods'). So that the real thickness of fibers is probably about $10 \mathrm{~nm}$. No consistent difference between $\mathrm{Ca}^{2+}$ and $\mathrm{Na}^{+}$containing buffers was seen. In the presence of $\mathrm{Na}^{+}$plus $\mathrm{Ca}^{2+}$ fibers appeared to be slightly thicker (about $30 \mathrm{~mm}$ in diameter), more closely interwoven or branched to form a mat-like structure (Panel E). Further aggregation of fibers to form thick bundles was also seen in the presence of $\mathrm{Na}^{+}$plus $\mathrm{Ca}^{2+}$ (Panel F). These data suggest that uromucoid molecules can polymerise in different ways depending on the physico-chemical environment. This concept is supported by examining hyaline casts from urine where similar loose fiber meshworks (Fig. 7, Panel A) and compact assemblies (Fig. 7, Panel B) can be seen.

Further studies were performed to confirm that uromucoid really was binding to the filters under non-blocking conditions (as was suggested by Fig. 6 Panel B

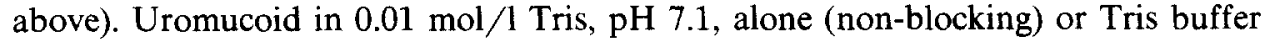
containing $60 \mathrm{mmol} / 1 \mathrm{NaCl}$ and $0.3 \mathrm{mmol} / 1 \mathrm{CaCl}_{2}$ (blocking) were each pushed through a filter. The filter was then removed and rinsed with the buffer alone. The protein bound to the filters was then washed off with $10 \%$ SDS containing $8 \mathrm{~mol} / \mathrm{l}$ 

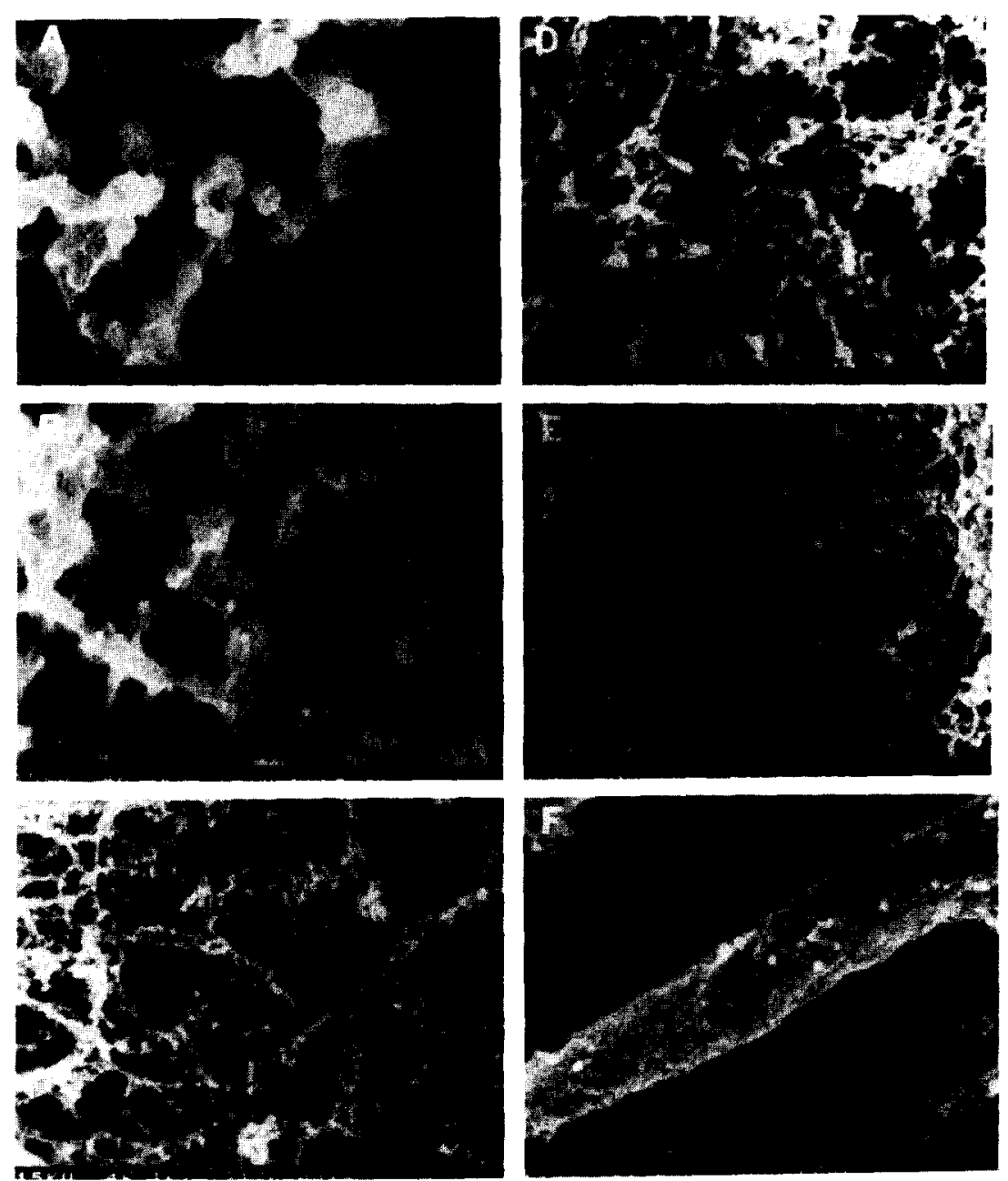

Fig. 6. Scanning electron micrographs of the Millipore filter surface following filtration of uromucoid under different conditions. Panel A shows the filter surface alone. Panel B shows the filter surface following filtration of uromucoid at $\mathrm{pH} 7.6$ in the absence of added $\mathrm{Na}^{+}$or $\mathrm{Ca}^{2+}$. Note that the filter surface is coated with uromucoid (see text for additional data providing further evidence that uromucoid does indeed stick to the filter surface under these conditions). Panel $\mathrm{C}$ shows a blocked filter surface following filtration of uromucoid in $1 \mathrm{mmol} / \mathrm{CaCl}_{2}$ at $\mathrm{pH}$ 7.6. Panel $\mathrm{D}$ shows a blocked filter surface following filtration of uromucoid in $100 \mathrm{mmol} / 1 \mathrm{NaCl}$ at $\mathrm{pH}$ 7.6. Panel $\mathrm{E}$ shows a blocked filter surface following filtration of uromucoid in the presence of both $1 \mathrm{mmol} / 1 \mathrm{Ca}^{2+}$ and $100 \mathrm{mmol} / 1 \mathrm{NaCl}$ at $\mathrm{pH}$ 7.1. Panel $F$ shows a filter surface following filtration of uromucoid in $250 \mathrm{mmol} / 1 \mathrm{NaCl}$. Panels $\mathrm{A}-\mathrm{E}$ are the same magnification (46100 times), and the white bar at the base of each photomicrograph represents $217 \mathrm{~nm}$. Panel F is magnified 61200 times, and the white bar represents $163 \mathrm{~nm}$.

urea. The initial solutions containing uromucoid, the filtrates and the washings (containing protein eluted from the filter) were analyzed on an SDS-PAGE gel, blotted onto nitrocellulose paper and stained for uromucoid using goat anti- 

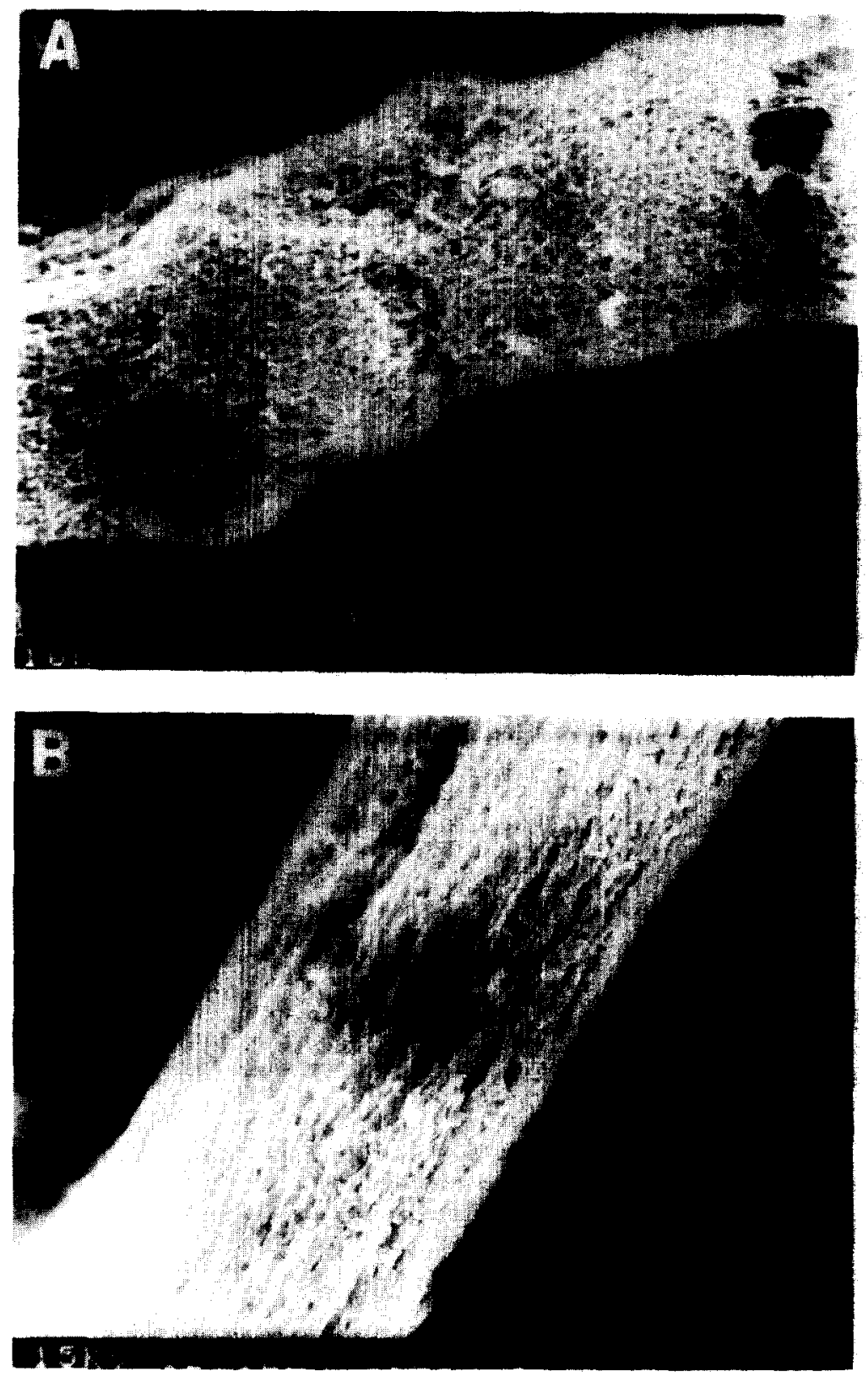

Fig. 7. Scanning electron micrographics of hyaline casts obtained from urine. The polymeric arrangement of uromucoid can be a loose meshwork of fibers (A) or a much denser arrangement of polymerised uromucoid (B). Panel A is magnified 5300 times and the bar represents. $1.9 \mu \mathrm{mol} / 1$. Panel B is magnified 12100 times and the bar represents $825 \mathrm{~nm}$. 


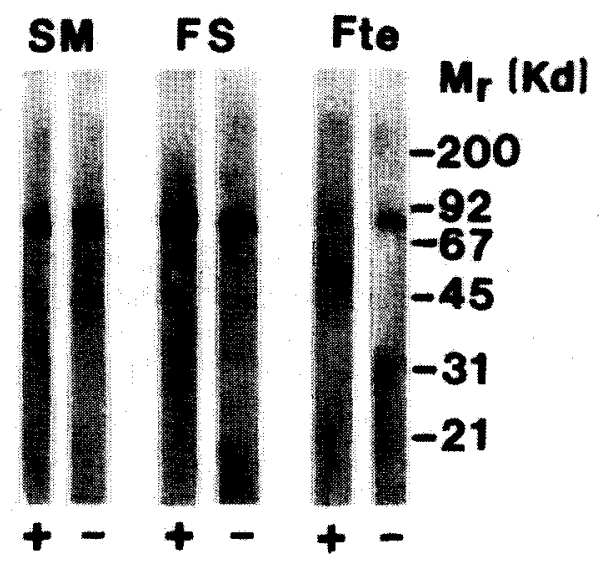

Fig. 8. Western blots of SDS-PAGEs stained for uromucoid protein using goat antihuman uromucoid and peroxidase-labelled antigoat IgG (see 'Materials and Methods'). In the experiment uromucoid (100

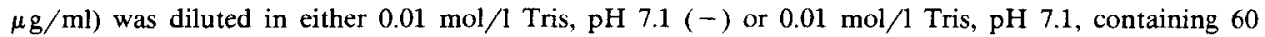
$\mathrm{mmol} / 1 \mathrm{NaCl}$ and $0.3 \mathrm{mmol} / 1 \mathrm{CaCl}_{2}(+)$. The blots of the starting material $(5 \mathrm{~mol} / 1)$ in each case are shown on the left side of the figure. Following filtration of $1 \mathrm{ml}$ of fluid in the case of $0.01 \mathrm{~mol} / 1 \mathrm{Tris}$ (unblocked) and $0.6 \mathrm{ml}$ fluid containing $0.01 \mathrm{~mol} / 1$ Tris plus $60 \mathrm{mmol} / 1 \mathrm{NaCl}$ and $0.3 \mathrm{mmol} / 1 \mathrm{CaCl}_{2}$ (blocked) the filters were rinsed in the above buffers and then washed in $10 \mu 1$ of $10 \%$ SDS $8 \mathrm{~mol} / 1$ urea to elute protein bound to the filter. The blots of both washings from the filter surface (FS) are shown in the middle of the figure and demonstrate that uromucoid could be eluted from both blocked and unblocked filters. The blots of the filtrate (Fte) which passed through the filter are shown on the right side of the figure and demonstrate that the filtrate contained no detectable uromucoid when $\mathrm{NaCl}$ and $\mathrm{CaCl}_{2}$ were present and only small amounts of uromucoid when $\mathrm{NaCl}$ and $\mathrm{CaCl}_{2}$ were absent. These results confirm that uromucoid bound to the filter surface in both sets of conditions tested.

uromucoid serum and a peroxidase-labelled antigoat IgG second antibody. The results are shown in Fig. 8. They confirm that uromucoid bound to the filter in both the presence and in the absence of ions. Small amounts of uromucoid passed through the filter to appear in the filtrate in the $0.01 \mathrm{~mol} / 1$ Tris experiment while no detectable uromucoid was present in the filtrate from the $0.01 \mathrm{~mol} / 1$ Tris buffer containing $\mathrm{Na}^{+}$and $\mathrm{Ca}^{2+}$. This result confirms that uromucoid did bind to the filter under nonblocking conditions.

A further study was performed to quantitate uromucoid binding to the filter surface even when it was not blocking the filter. For this experiment uromucoid was labelled with ${ }^{125} \mathrm{I}$ (see 'Materials and Methods'). The [ $\left.{ }^{125} \mathrm{I}\right]$ uromucoid was added to unlabelled uromucoid $(100 \mu \mathrm{g} / \mathrm{ml})$ and the mixtures tested for filter blocking activity in the presence of different ions. The radioactivity bound to the filter was then measured. In the presence of $1 \mathrm{mmol} / 1 \mathrm{Ca}^{2+}$ (which blocked the filter after 0.6 $\mathrm{ml}$ had been pushed through) $91.1 \%$ of the [ $\left.{ }^{125} \mathrm{I}\right]$ uromucoid was bound to the filter. In the presence of $0.01 \mathrm{~mol} / 1$ Tris, $\mathrm{pH} 7.6$ (which did not block the filter after $1 \mathrm{ml}$ had been pushed through), $80.8 \%$ of the $\left[{ }^{125} \mathrm{I}\right]$ uromucoid was bound to the filter. Similar results were obtained in two other experiments performed with a different batch of $\left.{ }^{125} \mathrm{I}\right]$ uromucoid and with $\mathrm{Na}^{+}$instead of $\mathrm{Ca}^{2+}$ in the buffer system. These 
results confirm that binding of uromucoid to the filter per se did not block the filter. Rather it was the presence of ions and the resulting polymeric arrangement of uromucoid protein that caused blocking of the filter.

Uromucoid can therefore exist in at least three arrangements. These are: (a) a smooth homogeneous coating of the filter surface as shown in Fig. 6 Panel A, (b) a loose meshwork of fibers linearly polymerized as shown in Fig. 6, Panels C and D and Fig. 7, Panel A and (c) a compact arrangements of fibers which are both linearly and laterally polymerized as shown in Fig. 6, Panel E and F and Fig. 7, Panel B.

\section{Discussion}

Our studies were prompted by the observation that it was impossible to push normal human urine through a $0.2-\mu \mathrm{m}$ Millipore filter, particularly when the urine was concentrated. Examination of the filter surface by scanning electron microscopy revealed fibrous structures which were shown by Western blotting to be uromucoid. The conclusion that the blocking effect was due to uromucoid was confirmed by finding that purified uromucoid would also block the filter.

The blocking effect was due to the arrangement of uromucoid molecules rather than due to binding per se. Thus, under optimal blocking conditions, the uromucoid formed a mat-like structure coating the filter surface. This arrangement was different from the loose meshwork of fibers which also blocked the filter or from the homogeneous coating of the filter surface by uromucoid seen when ions were absent and the filter was not blocked. Similar differences in arrangement of uromucoid polymer were scen in hyaline casts from urine. Uromucoid molecules can therefore exist in at least three different arrangements depending on ionic conditions. These are (a) linear polymers, (b) linear and lateral polymers that form clumps, and (c) a homogeneous coating of molecules such as was seen on the absence of ions.

Previous physicochemical studies have emphasized the effects of $\mathrm{H}^{+}, \mathrm{Ca}^{2+}$, and $\mathrm{Na}^{+}$on uromucoid protein aggregation by the use of light scattering, viscometric and centrifugation techniques $[1,7,11]$. In our studies using a simple filter-blocking assay a similar effect of ions and $\mathrm{pH}$ was found except that the effect of $\mathrm{Ca}^{2+}$ was seen between 0.04 and $0.4 \mathrm{mmol} / 1 \mathrm{Ca}^{2+}\left(32-320 \mathrm{~mol} \mathrm{Ca} \mathrm{Ca}^{2+} / \mathrm{mol}\right.$ uromucoid protein) at $\mathrm{pH} 7.1$ compared with previously reported effects at about $2 \mathrm{mmol} / 1$ $\mathrm{Ca}^{2+}$ [7,11]. However, previous calcium binding studies [1] have shown maximum $\mathrm{Ca}^{2+}$ binding prior to gel formation of $0.45 \mathrm{mmol} \mathrm{Ca}{ }^{2+} / \mathrm{g}$ uromucoid (about 36 mol $\mathrm{Ca}^{2+} / \mathrm{mol}$ uromucoid) which is similar to the threshold for filter-blocking activity found in this study.

The ultrastructure of the uromucoid protein monomer and the polymeric fiber-like arrangements of uromucoid protein have previously been studied using several tcchniques $[2,6,9,10]$. In particular, negative staining has revealed that fibers appear to consist of helical arrangements of uromucoid protein molecules $10-15 \mathrm{~nm}$ wide which appear to consist of chains of molecules with carbohydrate spicules or spherules projecting away from the protein core [2]. Fibers consisting of two uromucoid protein polymers arranged side-by-side were also seen [2]. The results 
reported in this study using scanning electron microscopy arc compatible with those previously described structures seen using other techniques although the fine detail was not visualized because of the thick $(10 \mathrm{~nm})$ gold/palladium coating. The blobs visualized by SEM which appeared to be randomly arranged on the fiber surface might be the carbohydrate structures described previously [2]. They might possibly he involved in the fiber-fiber interactions (lateral aggregation) required to form the mat-like structures seen on the filter surface in this study.

The fact that normal urine blocks filters implies that these very large polymeric structures are present in normal concentrated urine. We can therefore visualize urine as a type of gel. The function of this gel remains to be determined. One possibility is that the gel might function to maintain the patency of the tubular lumen and prevent its collapse. Thus as more and more water is removed in the collecting duct, the gel would self-assemble to form a scaffold in the shape of the tubular lumen. This idea is supported by the fact that hyaline casts of tubules which consist of polymerized uromucoid are frequently found in concentrated normal urine. An alternative hypothesis previously suggested is that the uromucoid which lines the external surface of cells of the ascending loop of Ilenle might form the water barrier necessary for the counter current mechanism to function $[3,15]$. For this purpose uromucoid molecules might assemble in the homogeneous coat arrangement seen on the filter surface in the absence of ions. Further studies are required to examine these possibilities.

\section{Acknowledgements}

This work was partly supported by a Grant-in-Aid from the American Heart Association and the Michigan branch of the American Heart Association and United States Public Health Service Grant AM 30673. Roger Wiggins is an Established Investigator of the American Heart Association.

\section{References}

1 Cleave AJ, Kent PW, Peacocke AR. The binding of hydrogen and calcium ions by Tamm-Horsfall glycoprotein. Biochim Biophys Acta 1972: 285: 208-233.

2 Delain E. Thiery JP, Coulard D, Joliviene A, Hartman L. Etude chimique et ultrastructurale de la glycoproteine de Tamm et Horsfall ou uromucoide. Biol Cell 1980: 39: 31-42.

3 Hoyer JR, Sisson SP, Vernier RL. Tamm-Horsfall glycoprotein. Ultrastructural immunoperoxidase localization in rat kidney. Lab Invest 1979: 41: 168-173.

4 Laemmli UK. Cleavage of structural proteins during the assembly of the head of bacteriophage $T_{4}$. Nature (London) 1970: 227: 680 .

5 Lowry OH, Rosebrough NJ, Farr AL. Randall RJ. Protein measurement with the folin phenol reagent. J Biol Chem 1951; 193: 265.

6 Maxfield M. Molecular forms of human urinary mucoprotein present under physiological conditions. Biochim Biophys Acta 1961; 49: 548-559.

7 McQueen EG, Engel GB. Factors determining the aggregation of urinary mucoprotein. J Clin Pathol 1966; 19: 392-396.

8 Merril CR. Switzer RC. Van Keuven ML. Trace polypeptides in cellular extracts and human hody fluids detected by two-dimensional electrophoresis and a highly sensitive silver stain. Proc Natl Acad Sci USA 1979: 76: 4335-4339. 
9 Porter KR, Tamm I. Direct visualization of a mucoprotein component in urine. J Riol Chem 1955; 212: $135-140$.

10 Robinson JP, Puett D. Morphological and conformational studies of Tamm-Horsfall urinary glycoprotein. Arch Biochem Biophys 1973; 159: 615-621.

11 Stevenson FK, Cleave AJ, Kent DW. The effect of ions on the viscometric and ultracentrifugal behavior of Tamm-Horsfall glycoprotein. Biochim Biophys Acta 1971; 236: 59-66.

12 Tamm I, Horsfall FL. Characterization and separation of an inhibitor of viral hemagglutination present in urine. Proc Soc Exp Biol Med 1950; 74: 108-114.

13 Wiggins RC. Agarose drop method for loading thin polyacrylamide gels. Ann Biochem 1982; 126 : $422-424$.

14 Wiggins RC, Glatfelter A, Kshirsagar B, Brukman J. Procoagulant activity in normal human urine is associated with subcellular particles. Kidney Int 1986; 29: 591-597.

15 Wirdnam PK, Milner RDG. Tamm-Horsfall glycoprotein release from rat kidney cortex slices in vitro. Clin Sci 1984; 67: 529-534. 